\title{
COMPREHENSIVE SEXUALITY EDUCATION SEBAGAI PENCEGAHAN TERHADAP KEKERASAN SEKSUAL PADA SISWA-SISWI SMP 8 SURABAYA
}

\author{
Merry Fridha ${ }^{1)}$, Astri Haryanti ${ }^{2)}$ \\ ${ }^{1}$ Fakultas Ilmu Sosial dan Ilmu Politik, Universitas 17 Agustus 1945 Surabaya \\ 2 Fakultas Psikologi, Universitas 17 Agustus 1945 Surabaya \\ email: ${ }^{1}$ merry_rafi@yahoo.co.id, ${ }^{2}$ astri.2707@gmail.com
}

\begin{abstract}
Abstrak
Kekerasan seksual di Jawa Timur menunjukkan angka yang memprihatinkan. Data Polda Jatim menunjukkan ada 117 anak yang mengalami kekerasan seksual selama bulan Januari-Februari 2018 di Jawa Timur (merdeka.com diunduh 12 Agustus 2019). Sebagian besar korban mengalami kekerasan seksual di rumah dan menyusul tempat kedua adalah sekolah. Permasalahan yang kerap terjadi pada korban kekerasan seksual adalah viktimasasi seksual yaitu korban merasa hal tersebut adalah aib sehingga kasus-kasus kekerasan seksual pun laksana gunung es, dimana banyak korban yang enggan atau tidak melaporkan. Oleh karena itu, upaya pencegahan kekerasan seksual diperlukan untuk memberikan pengetahuan kepada anak agar anak mampu melakukan deteksi diri terkait bahaya-bahaya yang bisa saja mengancam dimanapun dia berada. Upaya pencegahan ini diberikan dalam bentuk psikoedukasi kepada siswa-siswi SMP di SMP 8 Surabaya. Psikoedukasi yang diberikan berupa comprehensive sexuality education dengan diikuti oleh 54 partisipan. Efektivitas psikoedukasi diukur melalui pretest dan posttest untuk mengukur pemahaman siswa. Berdasarkan data yang diperoleh melalui kedua test tersebut maka dapat disimpulkan bahwa siswa memiliki perbedaan pengetahuan sebelum dan setelah diberikan materi terkait pendidikan seksual. Hal ini menunjukkan bahwa siswa mulai memahami hal apa saja yang sebaiknya dapat ia lakukan sehingga dapat terhindar dari kekerasan seksual, termasuk resiko yang akan diterima ketika mereka melakukan hubungan seksual.
\end{abstract}

Kata Kunci: Comprehensive Sexuality Education, Pencegahan, Kekerasan Seksual.

\begin{abstract}
Sexual violence in East Java shows an alarming number. East Java Regional Police data show there are 117 children who experienced sexual violence during January-February 2018 (Andriansyah, 2018). Most victims experienced sexual violence at home and followed the second place was school. The problem that often occurs with victims of sexual violence is sexual victimization that is the victim feels it is a disgrace that sexual violence cases are like an iceberg, where many victims are not reporting. Therefore, efforts to prevent sexual violence are needed to provide knowledge to children so that children are able to do self-detection related to dangers that could threaten wherever he is. These prevention efforts are given in the form of psychoeducation to junior high school students at SMP 8 Surabaya. The psychoeducation provided was in the form of comprehensive sexuality education with 54 participants. The effectiveness of psychoeducation is measured through pretest and posttest. Based on data obtained through the two tests, it can be concluded that students have different knowledge before and after being given material related to sexual education. This shows that students begin to understand what they should be able to do so that they can avoid sexual violence.
\end{abstract}

Keywords: Comprehensive Sexuality Education, Prevention, Sexual Violence. 


\section{PENDAHULUAN}

Pelecehan seksual merupakan isu yang selalu hangat untuk dibicarakan.Walaupun sering dibicarakan, namun isu ini dianggap sensitif sehingga banyak kalangan yang tidak secara terbuka mengungkapkan seks dengan segala permasalahannya sehingga kekerasan seksual menjadi fenomena gunung es. Fenomena kekerasan seksual merupakan permasalahan yang kerap terjadi di sekitar kita. Data Polda Jatim menunjukkan sebanyak 117 anak telah menjadi korban kekerasan seksual selama bulan JanuariFebruari 2018 (Andriansyah, 2018). Hal ini menunjukkan bahwa korban kekerasan tidak sedikit bahkan bisa jadi lebih banyak. Permasalahan yang kerap terjadi pada korban kekerasan seksual adalah viktimisasi berganda yaitu korban merasa hal tersebut adalah aib sehingga kasus-kasus kekerasan seksual pun laksana gunung es, dimana banyak korban namun mereka enggan atau tidak mau melaporkan.

Pada kalangan remaja putri, viktimisasi seksual memberikan dampak psikologis yang buruk, seperti depresi, gangguan stres pasca trauma, dan berbagai distress yang umum. Korban pelecehan seksual kerap kali tidak dapat menceritakan atau minta perlindungan kepada pihak lain karena dianggap momok yang memalukan. Pada kasus lain, seringkali seorang remaja putri yang telah melakukan hubungan seksual sebelum menikah, mereka cenderung akan memiliki self-esteem dan selfawareness yang rendah (Kennedy, dkk., 2011: 18).

Pandangan psikiater dr. Aimee Nugroho, SpKJ (dalam Jawa Pos, 13 Mei 2016) menyatakan bahwa pencabulan yang melibatkan pelaku dan korban remaja maupun anak-anak membuat anak-anak dibawah umur menjadi takut dan trauma sehingga dapat membuat mereka menutup diri dari lingkungan sosial. Pandangan tersebut tentu saja sangat merugikan dan dapat menjadi epidemi bagi remaja dan anak-anak dibawah umur.

Anak menuju remaja yang sedang mengalami masa transisional, menjadi fokus perhatian penulis. Dimana secara psikologis masa remaja adalah suatu fase tumbuh kembang yang sangat dinamis dalam kehidupannya. Definisi remaja menurut Hurlock adalah masa tumbuh untuk mencapai sebuah kondisi matang baik dari sisi emosional, sosial, psikis, juga mental (Hurlock dalam Maharani dan Wulanyani, 2018:227).

Dimasa remaja awal (usia SMP) banyak sekali keingintahuan anak terkait masalah seks, namun banyak dari orang tua yang mengangap hal ini adalah sesuatu yang tabu dan diannggap tidak layak untuk dibicarakan secara terbuka. Akibatnya sang anak akan mencoba mencari informasi dari sumber yang salah seperti misalnya melalui media sosial atau bahkan mencoba-coba seks sebelum waktunya ataupun hal lain, yang menjadi kekhawatiran adalah anak akan menjadi obyek dan korban kekerasan seksual karena ketidaktahuannya akan hal tersebut.

Ada berbagai macam bentuk pelecehan hingga kekerasan seksual. Berdasarkan catatan Komnas Perempuan, seperti segala bentuk pelecehan seksual baik verbal dan non verbal, percobaan perkosaan, intimidasi seksual seperti mengancam bila menolak, eksploitasi seksual misal penyebaran gambar-gambar atau video tidak senonoh, perdagangan perempuan, jebakan akan prostitusi paksa, pemaksaan perkawinan termasuk cerai gantung, pemaksaan agar hamil, pemaksaan untuk aborsi, pemaksaan untuk menggenakan alat kontrasepsi, segala bentuk penyiksaan seksual dan segala bentuk aturan yang tidak masuk akal serta diskriminasi dengan alasan norma suatu daerah ataupun agama (Komnas Perempuan, 2012:3). Segala jenis bentuk kekerasan seksual terhadap perempuan tersebut harus dafahami semua fihak agar tidak memakan korban.

Pada tahun 2019 Komnas Perempuan mencatat akan adanya peningkatan pengaduan pelecehan dan kekerasan terhadap perempuan dan anak di Indonesia sebanyak 14\%. Dimana pada 2019 terdapat 348.446 kasus pelecehan dan kekerasan terhadap perempuan dan anak. Dari temuan 
Komnas Perempuan diketahui bahwa pelaku pelecehan dan kekerasan seksual tersebut mayoritas adalah orang terdekat dari korban seperti ayah, paman, kakak, bahkan guru dengan berbagai jenis kasus termasuk inces atau perkosaan yang dilakukan saudara kandung.

Berbagai kejadian tindak kekerasan seksual, seperti diberitakan Jawa Pos pada mei 2016 silam mengungkap akan korban dan pelaku dibawah umur. Korban yang berusia 13 tahun dilecehkan oleh kekasihnya yang berusia 14 tahun serta 7 orang temanteman lainnya. Pelaku yang berjumlah 8 orang semuanya adalah anak-anak dibawah umur yaitu antara usia 9 tahun sampai14 tahun. Seluruh pelaku merupakan anak usia sekolah menegah pertama. bahkan ada yang masih kelas 3 SD. Hal ini tentunya sangat memprihatinkan. Terlebih diketahui bahwa korban pelecehan merupakan pacar korban dan telah dilakukan sejak 9 tahun yang lalu sejak korban masih berusia 4 tahun. Karena ketidak fahaman akan resiko yang mengintai pelaku terus melakukan pelecehan seksual tersebut karena sudah ketagihan. Selain itu korban juga merupakan pecandu obat-obatan terlarang sehingga hal ini menjadi kesempatan bagi pelaku untuk mengajak korban melakukan hubungan terlarang (Jawa Pos, 13 Mei 2016).

Peristiwa diatas tentu sangat memprihatinkan. Kepedulian dan perhatian dari berbagai pihak sangat diperlukan agar korban kekerasan seksual tidak terus bertambah. Baik dari orang tua, sekolah, maupun pihak-pihak lain yang peduli terhadap hal ini. Karena sejatinya anak merupakan masa depan sebuah bangsa. Ditangan anak-anaklah, cita-cita bangsa ini digantungkan. Maka untuk mencegah terjadinya tindak kekerasan seksual diperlukan pendidikan seksual yang komprehensif kepada anak-anak yang sedang dalam masa peralihan menuju remaja awal. Karena dimasa ini anak sedang bertansformasi secara fisik dan pemikiran sehingga rentan mendapatkan tindak kekerasan seksual yang tidak diinginkan.

Kegiatan pemberian psikoedukasi terkait dengan permasalahan yang meresahkan dalam masyarakat tentang kasus pelecehan seksual yang semakin marak, bertujuan untuk membentengi para perempuan dan anak-anak yang sedang dalam masa transisi sehingga terhindar dari segala bentuk kekerasan seksual. Oleh karenanya diperlukan pengetahuan, pendidikan, informasi, serta pelatihan pencegahan dan penanggulangan terjadinya kekerasan seksual. Secara spesifik psikoedukasi ini bertujuan untuk memberikan pengetahuan tentang kesehatan reproduksi dan informasi terkait kekerasan seksual yang mungkin saja dapat terjadi.

\section{KAJIAN LITERATUR}

Comprehensive Sexuality Education (CSE) merupakan pendekatan yang berbasis pada hak asasi dan fokus terhadap gender pada pendidikan seksualitas, yang dilakukan di sekolah maupun di luar sekolah. CSE merupakan pendidikan berbasis kurikulum yang dilakukan dengan cara memberi bekal kepada anak-anak serta remaja mengenai perihal dalam konteks perkembangan emosional dan sosial. Hal ini meliputi secara keseluruhan tentang seksualitas dan perilaku seksual, hingga pada pencegahan kehamilan dan penyakit menular seksual (UNFPA, 2014).

CSE memungkinkan anak-anak dan remaja untuk:

a. Memperoleh informasi yang akurat tentang seksualitas manusia, kesehatan seksual dan reproduksi, serta hak asasi manusia.

b. Mengembangkan sikap dan nilai-nilai positif serta kepedulian terhadap kesehatan seksual dan reproduksi dan mengembangkan harga diri, penghormatan terhadap hak asasi manusia dan kesetaraan gender. CSE memberdayakan kaum muda untuk mengendalikan perilaku mereka sendiri dan pada akhirnya memperlakukan orang lain dengan rasa hormat, penerimaan, toleransi dan empati, terlepas dari jenis kelamin, etnis, ras atau orientasi seksual. 

c. Mengembangkan keterampilan hidup yang mendorong pemikiran kritis, komunikasi dan negosiasi, pengambilan keputusan dan ketegasan.

Psikoedukasi menurut HIMPSI
(2010) merupakan sebuah upaya
peningkatkan pemahaman dan keterampilan
perempuan untuk mencegah munculnya
atau meluasnya gangguan psikologis karena
sebuah permasalahan sehingga perlu
ditingkatkan pemahamannya akan gangguan
yang dialaminya tersebut.
Menurut HIM

psikoedukasi dapat dilakukan dengan pelatihan atau tanpa pelatihan. Pelatihan mderupakan rangkaian kegiatan dengan tujuan untuk memberikan pengetahuan kepada peserta. Pelatihan psiko edukasi dapat dilakuakn oleh HIMPSI atau lembaga lain yang diakui. Rancangan pelatihan disusun oleh psikolog atau ilmuwan psikologi secara tepat untuk memberikan pemahan dan pelatihan yang tepat sesuai kebutuhan. Rencana pelatihan menggabungkan antara teori dan bukti ilmiah serta berorientasi pada tercapainya pemahaman bagi para peserta pelatihan. Psikolog atau mentor melakukan pelatihan psiko edukasi dengan:

a. Bentuk ceramah dimana psikolog atau mentor memberikan informasi.

b. Pemberian informasi melalui leaflet, pamflet, iklan layanan masyarakat ataupun media massa lain yang berisi edukasi kepada peserta.

c. Psikoedukasi tanpa pelatihan harus melauli tahapan asesmen, perencanaan program yang matang, implementasi program yang tepat, serta monitoring dan evaluasi program secara berkala.

d. Psikoedukasi non training dapat dilakukan namun harus sesuai dengan aturan dan kaidah-kaidah ilmu psikologi.

e. Psikoedukasi non training dapat dihentikan apabila ditemukan data yang tidak relevan.

f. Jika hasil psikoedukasi berjalan tidak sesuai harapan maka psikolog atau mentor wajib untuk mengembalikan kondisi peserta kepada keadaan semula.

Definisi dari kekerasan seksual adalah semua tindakan baik ucapan atau perbuatan dari seseorang untuk memperdaya orang lain serta membuatnya terlibat dalam aktivitas seksual tanpa dikehendaki oleh korban (yayasanpulih.org).

Bentuk-bentuk kekerasan seksual menurut Komnas Perempuan meliputi:

1. Perkosaan merupakan tindak pemaksaan hubungan seksual baik yang dilakukan dengan penis ke arah vagina, anus, atau mulut korban maupun jari tangan atau benda-benda lainnya. Biasanya perkosaan dilakukan dengan pemaksaan serta berbagai bentuk tindak kekerasan yang disertai dengan ancaman.

2. Intimidasi Seksual merupakan tindak ancaman yang bertujuan menimbulkan rasa takut atau terancam secara psikis pada korban. Intimidasi seksual bisa dilakukan secara verbal maupun non verbal.

3. Pelecehan Seksual yaitu tindakan yang tidak menyenangkan dan tidak dikehendaki baik berupa sentuhan pada organ seksual korban atau sekedar mengolok-olok fisik korban. Seperrti misalnya siulan, mengedip dengan genit, perkataan tidak senonoh, maupun menunjukkan gambar atau foto berbau pornografi, mencolek atau menyentuh bagian tubuh korban.

4. Eksploitasi Seksual merupakan sebuah tindakan yang bertujuan untuk mengambil keuntungan baik dalam bentuk finansial, atau yang lainnya. Eksploitasi seksual sering ditemui dengan korban perempuan-perempuan yang tidak memiliki akses kkemasalah ekonomi sehingga ia masuk dalam lingkaran hitam prostitusi atau pornografi.

5. Perdagangan perempuan merupakan sebuah tindakan yang menggunakan perempuan sebagai komoditas yang 
diperdagangkan.

6. Prostitusi Paksa adalah sebuah tindakan akan pemaksaan permpuan untuk melayani pihak-pihak gertentu secara seksual tanpa dikeheendaki korban.

7. Perbudakan Paksa yaitu sebuah tindakan dimana tubuh korban dianggap hanya pemuas seks sehingga pelaku berhak memiliki dan menjadikannya pemuas seks.

8. Pemaksaan Perkawinan, termasuk cerai gantung merupakan salah satu kekerasan seksual kepada perempuan dan perbuatan tidak menyenangkan.

9. Pemaksaan Kehamilan merupakan salah satu bentuk kekerasan seksual terdapat pemaksaan dan perempuan menjadi tidak memiliki otoritas terhadap dirinya sendiri. Hal ini dapat dialami oleh perempuan yang menjadi korban perkosaan dan dipaksa melanjutkan kehamilannya padahal kehamilan tersebut tidak dia inginkan. Kejadian lain juga dapat terjadi pada perempuan yang harus terus bereproduksi dan tidak diperbolehkan untuk menunda atau memberi jarak kehamilan dengan alasan agama bahwa anak akan membawa rezekinya masing-masing.

10. Pemaksaan Aborsi yaitu dimana seorang perempuan diancam dan dipaksa melakukan aborsi karena sesuatu hal.

dilakukan

Pengguguran kandungan yang

11. Pemaksaan kontrasepsi dan sterilisasi juga merupakan tindak kekerasan seksual karena dilakukan tanpa persetujuan dari korban.

12. Penyiksaan Seksual jelas merupakan salah satu bentuk kekerasan seksual karena melukai fisik korban ketika melakukan hubungan seksual.

13. Penghukuman tidak manusiawi dan bernuansa seksual, misalnya tuduhan zina yang berakibat pada perundungan padahal tidak ada sksi dan bukti yang valid.

14. Praktik tradisi bernuansa seksual juga merupakan tindak kekerasan seksual 15. Kontrol seksual melalui peraturan perundangan ataupun norma-norma terkadang merugikan perempuan dan sangat diskriminatif.

\section{METODE PELAKSANAAN}

Metode yang digunakan adalah berupa psikoedukasi yang diberikan kepada siswa guna memberikan pemahaman baru terkait dengan materi yang disampaikan. Pengukuran pemahaman dengan melihat hasil pretest dan posttest yang telah di isi siswa. Psikoedukasi diberikan dengan cara memberi materi keoada siswa dan mempertimbangkan acuan dari CSE dimana CSE mempertimbangkan hak asasi manusia dan kesetaraan gender yang juga terkait dengan perilaku seksual hingga pada penyakit menular seksual. Materi ini disusun dengan memberikan pemahaman kepada siswa terkait dengan kesetaran gender, pemahaman mengenai remaja serta tugas-tugas perkembangan remaja, perilaku seksual termasuk hal-hal yang tidak boleh dilakukan, penyakit menular seksual serta cara yang dapat dilakukan untuk menghindari penyakit menular seksual.

Dalam melaksanakan kegiatan Abdimas ini, dilakukan di SMP 8 Surabaya dan diikuti oleh 54 siswa sesuai arahan dari pihak sekolah. Penulis beserta tim berfokus pada penyuluhan mengenai perilaku seksual pada siswa-siswi SMP 8 Surabaya dan pelaksanaannya akan disesuaikan dengan tahapan perkembangan remaja dengan kurikulum berdasarkan panduan pendidikan seksual yang diselenggarakan oleh UNESCO tahun 2010 yakni: (1). Fokus pada tujuan kesehatan yang jelas pencegahan IMS, HIV dan / atau kehamilan. (2). Fokus secara sempit pada perilaku spesifik yang mengarah pada tujuan kesehatan ini (misalnya, tidak melakukan hubungan seks atau menggunakan kondom atau kontrasepsi lainnya), memberikan pesan yang jelas tentang perilaku seksual, dan cara mengatasinya. (3). Mengatasi beberapa risiko psikososial seksual dan faktor 
perlindungan (misalnya, pengetahuan, risiko yang dipersepsikan, nilai-nilai, sikap, persepsi norma, dan self-efficacy) (4) pencegahan dari tindak kekerasan seksual.

Dalam kegiatan psikoedukasi tersebut tahapan yang akan dilakukan adalah: (1). Melakukan pretest untuk mengetahui pemahaman siswa-siswi SMP 8 Surabaya terhadap materi terkait pendidikan seksual (2). Memberikan sosialisasi tentang pendidikan seksual sesuai jenjang usia dan pemahanan tentang bentuk-bentuk kekerasan seksual, dan (3) Memberikan post-tes untuk mengukur pemahaman siswa-siswi setelah psikoedukasi berlangsung (4) Pemahaman tentang tindak kekerasan seksual. Kegiatan yang dilaksanakan, metode pengajaran dan pesan perilaku yang sesuai dengan budaya remaja, usia perkembangan dan pengalaman seksual. Sedangkan topik yang dibahas sesuai urutan logis.

Berikut penjelasan program psikoedukasi yang dilakukan:

1. Sebelum Comprehensive Sexuality Education dilakukan, siswa-siswi diminta mengisi pretest untuk mengukur pengetahuan siswa-siswi tentang permasalahan terkait.

2. Melakukan Comprehensive Sexuality Education dengan metode ceramah, dialog dan role playing

3. Meminta siswa-siswi mengisi postest untuk mengukur pemahaman akan materi yang telah disampaikan.

4. Melakukan screening terhadap hasil pretest dan post test

5. Menyimpulkan hasil Comprehensive Sexuality Educationyang telah dilakukan.

6. Melakukan Pendampingan lebih lanjut bila ditemukan korban tindak kekerasan seksual.

\section{HASIL DAN PEMBAHASAN}

Dalam program psikoedukasi dengan metode Comprehensiv Sexuality Educationyang dilakukan di SMP 8 Surabaya. Penulis dan tim melibatkan partisipan sejumlah 59 siswa, yang terdiri dari 15 orang siswa laki-laki dan 44 orang siswi perempuan. Partisipan merupakan perwakilan dari kelas 7 hingga kelas 8 dengan rentang usia 12-14 tahun. Sedangkan tim Psikoedukasi terdiri dari 2 orang dosen yang merupakan dosen fakultas psikologi dan fakultas ilmu sosial dan ilmu politik jurusan ilmu komunikasi yang memiliki keahlian dibidang ini. Dalam pelaksanaan kegiatan ini tim dosen dibantu oleh 2 orang mahasiswa sebagai asisten dilapangan.

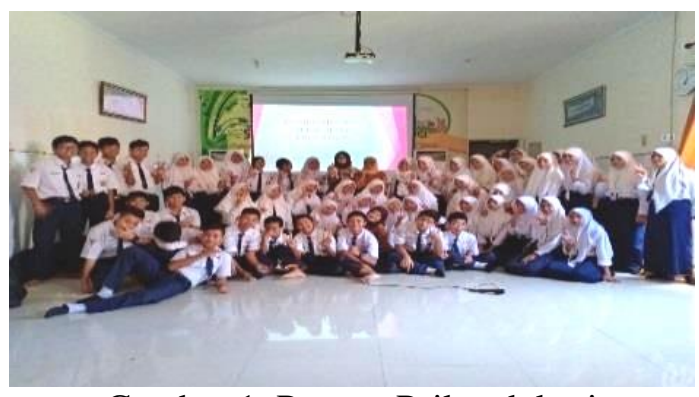

Gambar 1. Peserta Psikoedukasi

Comprehensive Sexuality Education

Dari keseluruhan partisipan yang mengikuti psikoedukasi, mereka diminta untuk mengisi lembar pretest dan postest untuk mengukur pemahaman siswa terkait dengan materi yang diberikan. Hasil pretest dan postest selanjutnya dianalisis dengan uji statistiknon-parametrik berupa Wilcoxon Signed Rank Test. Pertanyaan kedua test tersebut berjumlah 28, yang berisikan pertanyaan-pertanyaan seputar organ intim, permasalahan seksualitas, kekerasan seksual, dan pengetahuan umum seputar gender.

Hasil pretest dan postest digunakan untuk menguji pengetahuan partisipan terhadap masalah seksualitas. Hasil Uji menunjukkan signifikansi pada Asymp.Sig (2-tailed) senilai $0.000 . \quad$ Berdasarkan penghitungan uji perbedaan maka angka tersebut menunjukkan terdapat perbedaan pengetahuan terkait pendidikan seksual sebelum partisipan mengikuti program Comprehensive Sexuality Education dengan setelah mengikuti program. Program ini dinilai berhasil dalam rangka mencegah tindak kekerasan seksual pada siswa-siswi dan menambah pengeahuan partisipan terkait 
masalah seksualitas.

Setelah mengikuti program Comprehensive Sexuality Education terlihat bahwasiswa memiliki pemahaman mengenai pendidikan seksual, yang meliputi perilaku seksual beresiko yang mengarah pada pelecehan seksual serta dampak maupun konsekuensi yang dapat ditimbulkan dari perilaku yang berujung pada pelecehan seksual. Psikoedukasi yang diberikan mampu memberikan pemahaman yang lebih baik sesuai dengan tujuan dari psikoedukasi bahwa psikoedukasi dapat mencegah berbagai gangguan baik dalam hal pendidikan maupun psikologis (Brown, 2004).

Psikoedukasi dapat memberikan
informasi untuk membantu peserta mengatasi krisis, masalah perkembangan, atau pencegahan terhadap masalah. Penyebaran informasi merupakan hal yang penting dan difokuskan pada topik tertentu, yang mana psikoedukasi ini berfokus pada topik pendidikan seksual yang ditujukan pada remaja awal dengan konsep materi yang diberikan disesuaikan dengan usia perkembangan siswa berdasarkan acuan dari UNESCO dengan kurikulum tahun 2010 berdasarkan panduan pendidikan seksual yakni: (1). Fokus pada tujuan kesehatan yang jelas - pencegahan IMS, HIV dan / atau kehamilan. (2). Fokus secara sempit pada perilaku spesifik yang mengarah pada tujuan kesehatan ini (mis., Tidak melakukan hubungan seks atau menggunakan kondom atau kontrasepsi lainnya), memberikan pesan yang jelas tentang perilaku ini, dan mengatasinya. (3). Mengatasi beberapa risiko psikososial seksual dan faktor perlindungan (misalnya pengetahuan, risiko yang dipersepsikan, nilai-nilai, sikap, persepsi norma, dan self-efficacy) (4) pencegahan dari tindak kekerasan sexual dengan metode roleplay;suatu bentuk permainan yang dirancang sedemikian rupa yang disusun dengan skenario untuk memberikan bekal kepada siswa-siswi membentengi diri dari bentuk kekerasan seksual.

Pengetahuan dan pendidikan seksual menjadi pembahasan yang penting yang dibutuhkan oleh para remaja, karena dengan kurangnya pengetahuan mengenai pendidikan seksual dapat menyebabkan siswa mencari informasi yang salah. Untuk itu diperlukan informasi yang tepat baik secara formal dari institusi pendidikan maupun secara informal dari keluarga tentang seks. Namun yang banyak ditemukan pendidikan seks informal jarang sekali diberikan orang tua, hal ini disebabkan masih banyak orang tua maupun orang dewasa yang menganggap tabu atau kurang nyaman apabila membicarakan permasalahan seksualitas terhadap anak sehingga pemahaman yang tidak tepat seringkali diperoleh siswa karena mereka cenderung mencari dari teman sendiri dan menjadikannya sebagai bahan candaan.

Permasalahan seksual remaja timbul karena meningkatnya libido seksualitas yang penyaluran hasratnya tidak tepat, adanya tabu- larangan yang mengakibatkan sulitnya komunikasi antara orang dewasa dan anak remaja untuk berdiskusi mengenai perilaku seksual, kurangnya informasi tentang seks sehingga remaja seringkali mendapatkan informasi yang salah mengenai seks dan pergaulan yang semakin bebas yang akan berakibat fatal.

Psikoedukasi ini dinilai tepat karena dapat menjembatani informasi yang tidak tersampaikan oleh orang tua kepada anak. Pengetahuan dan pendidikan seksual secara komprehensif yang didapat akan membekali partisipian untuk lebih menghargai diri serta membentengi diri dari tindak kekerasan seksual. Pemahaman yang lebih baikterkait dengan perilaku seksual dapat diterima dengan metode comprehensive sexuality education.

\section{KESIMPULAN}

Comprehensive Sexuality Education merupakan program psikoedukasi dimana program ini berupaya memberikan pencegahan kekerasan seksual. Melalui program ini siswa-siswi akan diberi pengetahuan agar mampu melakukan deteksi diri terkait bahaya-bahaya yang bisa saja 
mengancam dimanapun dia berada. Program ini diberikan kepada siswa-siswi SMP 8 Surabaya dengan jumlah siswa yang mengikuti Psikoeduasi yaitu 54 orang, dimana 15 orang siswa laki-laki, dan 44 siswi peremouan. Untuk mengetahui efektifitas dari pemberikan materi pendidikan seksual secara komprehensif ini, maka siswa diminta untuk mengisi pretest sebelum mengikuti program, dan setelah mengikuti program, siswa diminta kembali untuk menjawab postest guna mengukur pemahaman siswa. Berdasarkan data yang diperoleh melalui kedua test tersebut maka dapat disimpulkan bahwa siswa memiliki perbedaan pengetahuan sebelum dan setelah mengikuti program psikoeduksi. Hal ini menunjukkan bahwa siswa-siswi mulai memahami hal apa saja yang sebaiknya dapat ia lakukan sehingga dapat terhindar dari kekerasan seksual, termasuk resiko yang akan diterima ketika mereka melakukan hubungan seksual. Setelah kegiatan pengabdian dilakukan baik siswa maupun pihak sekolah dapat menjadi lebih memperhatikan terhadap perilaku mereka. Sekolah dapat melakukan pengawasan kepada siswa dan siswa dapat lebih hati-hati dalam bertindak. Kegiatan inipun untuk melihat apakah terdapat siswa yang pernah mengalami tindak kekerasan seksual. Berdasarkan hasil screening yang dilakukan, bahwa tidak ditemukan siswa yang mengalami tindak kekerasan seksual. Pada akhirnya kegiatan ini dapat menjadi salah satu upaya agar siswa dapat mawas diri.

\section{REFERENSI}

Andriyansyah, M. (2018, Februari). KPAI prihatin angka kejahatan seksual pada anak di jatim masih tinggi. Merdeka [on- line]. Diakses pada tanggal 12 Agustus 2019 dari https://www.merdeka.com/peristiwa/ kpai- prihatin-angka-kejahatanseksual-pada- anak-di-jatim-masihtinggi.html.

Booklet Komnas Perempuan. (2012). Kekerasan Seksual, Kenali dan Tangani.

Brown, Nina. (2004). Psychoeducational Groups, $2^{\text {nd }}$ Edition : Process and Practice. New York: BrunnerRoutledge.

HIMPSI. (2010). Kode etik psikologi Indonesia. Jakarta: Pengurus Pusat Himpunan Psikologi Indonesia.

Maharani, Ni Luh \& Wulanyani, Ni Made. (2018). Gambaran Harga Diri Remaja Putri yang Melakukan Seks Pra Nikah. Jurnal Psikologi Udayana, Vol 5 No 2.

Kejahatan Seksual di Sekitar Kita. (2016, 6 Mei). Jawa Pos, hlm. 1

Kennedy, A. C; Bybee, D; Kulkami, S. J; Archer, G. (2012). Seksual Victimization and Family Violence Among Urban African American Adolescent Women: Do Violence Cluster Profiles Predict Partner Violence Victimization and Sex Trade Exposure? Journal of Violence Against Women.

Mengenali Kekerasan Seksual. Diakses dari http://yayasanpulih.org/2017/06/men gena li-kekerasan-seksual/ pada tanggal 14 Agustus 2019.

Sarwono, S.W. (2007). Psikologi remaja. Jakarta: PT Raja Grafindo Persada

Stuart dan Sundeen.1998. Buku Saku Keperawatan Jiwa. Edisi 3. Jakarta: EGC. United Nations Population Fund (UNFPA). (2014). UNFPA operational guidance for comprehensive sexuality education: A focus on human rights and gender. New York: UNFPA 